\title{
Multivariate morphometric variability in sardine, Amblygaster clupeoides (Bleeker, 1849), from the Bay of Bengal coast, Bangladesh
}

Md Abu Hanif ${ }^{1 *}$ (D), Muhammad A. B. Siddik ${ }^{1}$ Md Aminul Islam², Md Reaz Chaklader ${ }^{1,3}$ and Ashfaqun Nahar ${ }^{4}$

\begin{abstract}
Background: Sardine Amblygaster clupeoides is a reef-associated oceanic species having long-standing socioeconomic and ecological importance along the coast of Bay of Bengal, Bangladesh, but less is known about the morphometric variability of the species. To uncover this, morphometric variability of $A$. clupeoides based on truss network technique was employed

Results: A total number of 160 specimens from four coastal regions (Sundarbans, Kuakata, Bhola, and Cox's Bazar) of the Bay of Bengal coast were used to determine whether separate populations could be distinguished. To test the hypothesis of differentiation, each sample was subjected to morphometric measurements consisting of twenty-eight landmarks. In one way ANOVA analysis, twenty-six out of 28 morphometric measurements showed significant differences among the four populations. The principal component analysis indicated shape variation and explained $70.11 \%$ of the total variance. About $68.39 \%$ of individuals into their original group were correctly classified in discriminating space, as determined by discriminant function (DF) analysis.

Conclusion: Morphometric traits like body length, body depth, body diagonal, body height, head length, head depth, mouth length, anal fin length, dorsal fin length, and caudal length diagonal were mainly responsible for variation and discrimination of populations. The present investigation demonstrates that the population of the east coast (Cox's Bazar) is morphometrically different from other populations. Future stock assessment of $A$. clupeoides should be considered especially on the east coast (Cox's Bazar) while formulating management action plans.
\end{abstract}

Keywords: Stock assessment, Truss network system, Population, Conservation

\section{Background}

Measuring stock status of a fish species is crucial for fisheries management, as stocks with different life history traits are essential to enhance yield as well as for stock management program (Siddik, Hanif, Chaklader, Nahar, \& Fotedar, 2016). Morphometry is a cost-effective technique frequently employed for describing fish body shape which is required to identify fish stocks, to delineate stock status, to discriminate between fish populations, and to link

\footnotetext{
* Correspondence: mahanif.pstu@gmail.com

'Department of Fisheries Biology and Genetics, Patuakhali Science and

Technology University, Patuakhali 8602, Bangladesh

Full list of author information is available at the end of the article
}

ontogeny with functional morphology of a species (Hanif et al., 2019; Torres, Gonzalez, \& Pena, 2010). It is also imperative to collect actual biological information of fish such as ecology, evolution, behavior, and stock assessment (Hanif, Siddik, Chaklader, Pham, \& Kleindienst, 2017; Islam et al., 2017; Silva, 2003; Yakubu \& Okunsebor, 2011) linked with diverse species, subspecies, and races (Chaklader et al., 2016). The truss network system is considered superior to traditional morphometrics that use morphometric traits to represent the complete shape of fish, which has been commonly used in the field of fish taxonomy and fisheries management (Francoy, Franco, \& Roubik, 2012; Sen et al., 2011; Turan, 2004). A number of 
studies has been conducted based on truss network system worldwide including Caspian lamprey (Caspiomyzon wagneri), black stripe minnow (Alosa pseudoharengus), Alewife (Alosa pseudoharengus), roho labeo (Labeo rohita), and so on (Cronin-Fine et al., 2015; Galeotti, Castalanelli, Groth, McCullough, \& Lund, 2015; Mir, Sarkar, Dwivedi, Gusain, \& Jena, 2012; Solomon, Okomoda, \& Ogbenyikwu, 2015; Vatandoust, Mousavi-Sabet, RazeghiMansour, AnvariFar, \& Heidari, 2015), but its application in the coast of Bangladesh is still scarce.

The southern coastal belt of Bangladesh is prosperous in fish and fisheries resources (Hanif, Siddik, Chaklader, Nahar, \& Mahmud, 2015; Hanif, Siddik, Nahar, Chaklader, \& Fotedar, 2017; Siddik, Chaklader, Hanif, Islam, \& Fotedar, 2016; Siddik et al., 2016; Siddik, Hanif, Chaklader, Nahar, \& Mahmud, 2015), where the Bay of Bengal solely provides a large number of marine fisheries resources to Bangladesh (Hussain \& Hoq, 2010). The genus Amblygaster includes three species, one being the Bleeker smoothbelly sardinella, Amblygaster clupeoides (Culpiformes: Clupeidae), the focus of this study. A. clupeoides is a reef-associated oceanic species, distributed in marine waters along the Indo-West Pacific regions including the coast of the Bay of Bengal, Indonesia, eastward to Fiji, and is also reported from Tonga and New Caledonia (Randall et al., 2004; Wantiez, 1993). Morphologically, the body is moderately cylindrical, the belly is rather rounded, and scutes are not prominent. A similar species Amblygaster sirm is distinguished from A. clupeoides by the presence of round black spots along the flank. A. clupeoides is a pelagic fish and generally found in large schools.

In Bangladesh, a large proportion of fish species in the coastal region remain unassessed due to insufficient scientific study. There is no stock structure information available for A. clupeoides population in the Bay of Bengal. The present research is therefore designed to examine the morphometric differences of A. clupeoides in their natural habitats, four coastal regions (Sundarbans, Kuakata, Bhola, and Cox's Bazar), of the Bay of Bengal.

\section{Methodology}

\section{Sample collection and identification}

A total of $160 \mathrm{~A}$. clupeoides were collected directly from fishermen immediately after catch. Methods of capture included gill net (mesh size $6.5 \mathrm{~cm}$ ) and coastal set bag net (mouth mesh size $12 \mathrm{~cm}$, middle $4 \mathrm{~cm}$, and cod end 0.5 $\mathrm{cm})$. The study occurred over a 6-month period from March 2015 to August 2015 from four coastal regions (Sundarbans, Kuakata, Bhola, and Cox's Bazar) of the Bay of Bengal coast. The fish were transported to the laboratory in chilled polystyrene boxes for further identification and morphometric measurements. Phenotypic characteristics were used to identify fish species. Sampling sites locations, dates, number of samples analyzed, and the GPS coordinates (latitude and longitude) are displayed in Table 1 and Fig. 1.

\section{Laboratory work}

In the present study, truss-based technique was used for $A$. clupeoides where a truss box for each sample was created by joining 13 points to make a total of 28 measurements (Table 2 and Fig. 2) for representing the outline of fish (Strauss \& Bookstein 1982). Total length and standard length (SL) were also collected which had been removed by allometric transformation to avoid size effect and were not used for further analysis. All measurements were taken to the nearest $0.1 \mathrm{~cm}$ by the same person from the left side of each de-frozen samples within 1 month time to ensure similar period between death and freezing, which might have impact on the results of the study. We employed a manual method where morphometric data were collected by placing the fish on water-resistant graph paper and measured by piercing the paper with a needle, corresponding to the anatomical landmarks.

\section{Statistical analysis}

To minimize size-related dissimilarity, all morphometric variables were amended by adjusting an allometric approach as proposed by Elliott, Haskard, and Koslow (1995):

$$
M_{\mathrm{adj}}=M(\mathrm{Ls} / \mathrm{Lo})^{b}
$$

where $M$ is the original measurement, $M_{\text {adj }}$ is the sizecorrected measurement, Ls is the overall mean of standard length for all samples in each analysis, Lo is the standard length, and $b$ is the slope of the regression of $\log M$ on $\log$ Lo using all fish from each group. Significance test of correlating coefficient was applied between transformed variables and standard length to check if the transformation was successful in eliminating the size effects from the entire dataset. One way ANOVA for 28 morphometric traits was performed to estimate the significant variation among the four locations. For the current study, principal component (PC) analysis, discriminant function (DF) analyses, and cluster analysis (CA) were performed to differentiate the four populations. For decreasing redundancy among the morphometric variables and removing plentiful autonomous variables for population distinction (Samaee, Patzner, \& Mansour, 2009; Veasey, Schammass, Vencovsky, Martins, \& Bandel, 2001), principal component analysis was used. The Wilks' lambda $(\lambda)$ was used to assimilate the variation between and among the entire populations. To compute correctly classified percentage of fish samples, the discriminate function (DF) analysis was used. The 
Table 1 Summary of A. clupeoides samples (sampling sites, dates, geographical locations, and numbers of the collected fish sample) used in morphometric analysis

\begin{tabular}{|c|c|c|c|c|c|c|c|c|}
\hline \multirow[t]{2}{*}{ Sample } & \multirow{2}{*}{$\begin{array}{l}\text { Collection } \\
\text { site }\end{array}$} & \multirow[t]{2}{*}{ Date } & \multirow[t]{2}{*}{ Latitude } & \multirow[t]{2}{*}{ Longitude } & \multicolumn{4}{|c|}{ Collected sample } \\
\hline & & & & & $\mathrm{F}_{1}$ & $F_{2}$ & $\mathrm{~F}_{3}$ & Tota \\
\hline 1 & Cox's Bazar & 12 April 2015 & $21^{\circ} 82^{\prime} \mathrm{N}$ & $89^{\circ} 50^{\prime} \mathrm{E}$ & 17 & 9 & 14 & 40 \\
\hline 2 & Kuakata & 26 July 2015 & $21^{\circ} 83^{\prime} \mathrm{N}$ & $90^{\circ} 25^{\prime} \mathrm{E}$ & 40 & - & - & 40 \\
\hline 3 & Bhola & 03 August 2015 & $21^{\circ} 90^{\prime} \mathrm{N}$ & $90^{\circ} 60^{\prime} \mathrm{E}$ & 40 & - & - & 40 \\
\hline 4 & Sundarbans & 17 September 2015 & $21^{\circ} 50^{\prime} \mathrm{N}$ & $92^{\circ} 00^{\prime} \mathrm{E}$ & 13 & 27 & - & 40 \\
\hline
\end{tabular}

$F_{1}, F_{2}$ and $F_{3}$ indicate fishermen by whom fish samples were collected

probable errors of the classification functions were calculated through cross-validation. The StatSoft STATISTICA (version 11.50), SPSS (version 16.1.0), Minitab (version 15.1.30), and Excel (Microsoft Office 2007) were used for statistical analyses.

\section{Results}

The length ranges and means with standard errors of length for specimens collected from four locations of the Bay of Bengal coast are shown in Table 3 separately. The population of each stock was more or less similar in size range from $17.8-23.4 \mathrm{~cm}, 17.2-$ $23.7 \mathrm{~cm}, 17.5-23.2 \mathrm{~cm}$, and $17.3-23.4 \mathrm{~cm}$ with mean value 20.6, 20.1, 20.2, and 20.3 for Sundarbans, Kuakata, Bhola, and Cox's Bazar, respectively (Fig. 3). Although their average size is much close to each other, their average weight showed significant difference which may be due to their morphometric difference. Among the morphometric measurements, one-way ANOVA test showed that 26 truss measurements out

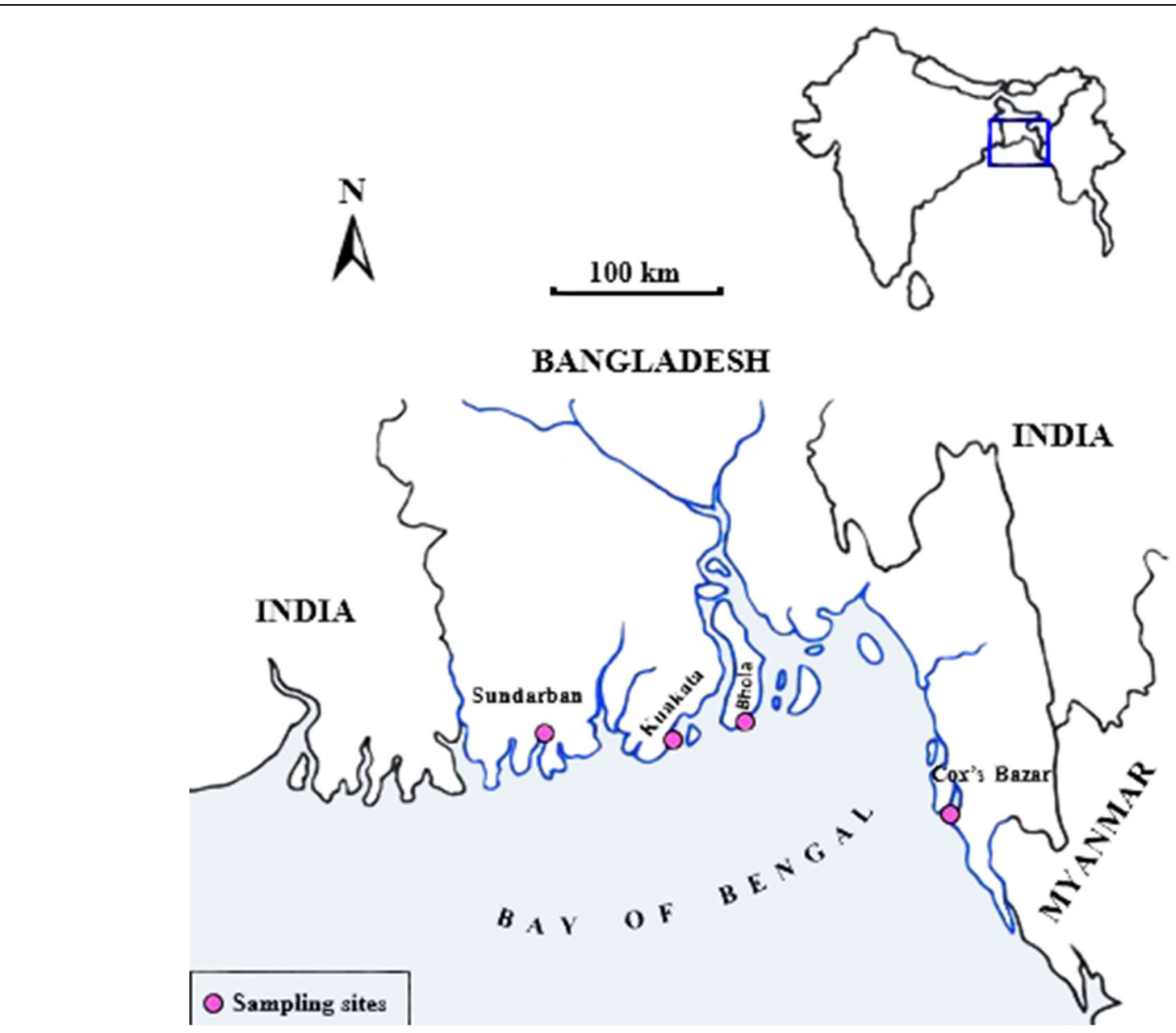

Fig. 1 Sampling locations of sardine A. clupeoides samples from Cox's Bazar, Kuakata, Bhola, and Sundarbans along the Bay of Bengal coast, Bangladesh 
Table 2 Morphometric measurements made for each sample of A. clupeoides collected from the Bay of Bengal coast, Bangladesh

\begin{tabular}{|c|c|c|c|}
\hline Measurement number & Distance code & Distance & Landmarks \\
\hline 1 & $\mathrm{HL} 1$ & Head length 1 & $1-2$ \\
\hline 2 & $M L$ & Mouth length & $1-12$ \\
\hline 3 & BL 1 & Body length 1 & $2-3$ \\
\hline 4 & BD 1 & Body diagonal 1 & $2-9$ \\
\hline 5 & $\mathrm{HH} 1$ & Head height 1 & $2-11$ \\
\hline 6 & HD 1 & Head diagonal 1 & $2-12$ \\
\hline 7 & HD 2 & Head diagonal 2 & $2-13$ \\
\hline 8 & DFL & Dorsal fin length & $3-4$ \\
\hline 9 & BD 2 & Body diagonal 2 & $3-9$ \\
\hline 10 & $\mathrm{BH} 1$ & Body height 1 & $3-10$ \\
\hline 11 & $\mathrm{BD} 3$ & Body diagonal 3 & $3-13$ \\
\hline 12 & BL 2 & Body length 2 & $4-5$ \\
\hline 13 & BD 4 & Body diagonal 4 & $4-7$ \\
\hline 14 & BD 5 & Body diagonal 5 & $4-9$ \\
\hline 15 & BD 6 & Body diagonal 6 & $4-10$ \\
\hline 16 & BD 7 & Body diagonal 7 & $4-11$ \\
\hline 17 & $C L 1$ & Caudal length 1 & $5-6$ \\
\hline 18 & $\mathrm{BH} 2$ & Body height 2 & $5-7$ \\
\hline 19 & CLD & Caudal length diagonal & $5-8$ \\
\hline 20 & $\mathrm{BD} 8$ & Body diagonal 8 & $5-10$ \\
\hline 21 & $\mathrm{CL} 2$ & Caudal length 2 & $6-7$ \\
\hline 22 & BL 3 & Body length 3 & $7-8$ \\
\hline 23 & AFL & Anal fin length & $8-9$ \\
\hline 24 & BL 4 & Body length 4 & $9-10$ \\
\hline 25 & BL 5 & Body length 5 & $10-11$ \\
\hline 26 & BD 9 & Body diagonal 9 & $10-13$ \\
\hline 27 & $\mathrm{HL} 2$ & Head length 2 & $11-12$ \\
\hline 28 & HD 3 & Head diagonal 3 & $11-13$ \\
\hline
\end{tabular}

of 28 were highly significant $(p<0.001)$ (Table 4$)$. All measurements were further tested using PCA and DFA. These characteristics significantly varied among the four collection areas and were used in DF and PC analyses; hence, the data was pooled for all subsequent analyses.
Major differences in morphological measurements of A. clupeoides from the four distinct regions were uncovered by principal component analysis (PCA). The PC analysis of 28 morphometric measurements yielded five principal components explaining $84.75 \%$ of the total variance $(60.42 \%$ for $\mathrm{PC} 1,9.61 \%$ for $\mathrm{PC} 2,5.61 \%$ for $\mathrm{PC} 3$,

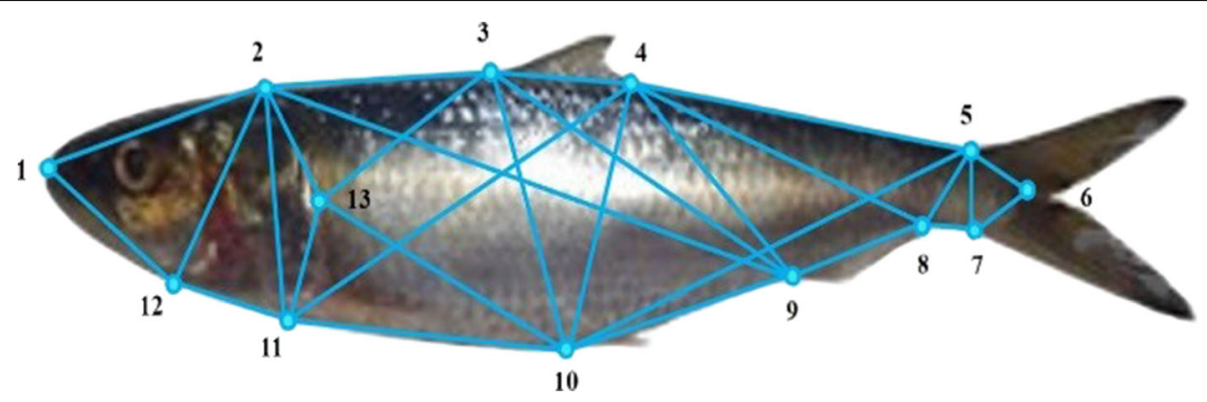

Fig. 2 Location of 13 landmarks and scheme of the truss network used in A. clupeoides morphometric analysis 
Table 3 Descriptive data of sardine A. clupeoides samples from the Bay of Bengal coast, Bangladesh

\begin{tabular}{|c|c|c|c|c|}
\hline \multirow[t]{2}{*}{ Population } & \multirow{2}{*}{$\begin{array}{l}\text { Sample } \\
\text { size }(n)\end{array}$} & \multicolumn{2}{|l|}{ Length (SL) } & \multirow{2}{*}{$\begin{array}{l}\text { Body weight } \\
\text { Mean } \pm \text { SE }\end{array}$} \\
\hline & & Length range $(\mathrm{cm})$ & Mean \pm SE & \\
\hline ans & 40 & 13.20 & $16.52 \pm 0.42$ & $=4.92$ \\
\hline Kuakata & 40 & $12.80-16.70$ & $14.60 \pm 0.13$ & $52.29 \pm 1.24$ \\
\hline Bhola & 40 & $13.20-16.90$ & $14.49 \pm 0.14$ & $55.26 \pm 0.98$ \\
\hline Cox's Bazar & 40 & $11.50-17.30$ & $14.91 \pm 0.20$ & $49.29 \pm 1.69$ \\
\hline
\end{tabular}

$5.01 \%$ for PC4, and $4.02 \%$ for PC5) in the entire dataset, with eigenvalues of $16.92,2.71,1.57,1.40$, and 1.13 , respectively (Table 5). PC1 and PC2 explained total $70.11 \%$ variance, and a closer investigation on these components was undertaken. In five PCAs, the mean loadings for the selected four regions differed remarkably in body morphology and also head morphology.

The PC1 was essentially a divergence between the measurements of fish head and fish body (Table 6 and Fig. 4a) except head length 1 , head diagonal 1 , dorsal fin length, body height 1 , body diagonal 5 , body diagonal 6 , body height 2 , caudal length 2 , anal fin length, body length 4, and head length 2 which were dominated by PC2, PC3, PC4, and PC5. A. clupeoides from Cox's Bazar were found to possess a smaller body dimensions and larger head than the other populations, while the samples collected from Sundarbans had increased body height and diagonal body dimensions, which clearly distinguished the two distinct populations (Fig. 4b).

PC1 (first principal component) detailed the differences in all parts except HL1, HD1, DFL, BH1, BD5, BD6, BH2, AFL, BL4, and HL2 (Fig. 5). PC1 score means $(p<0.001)$ indicated a highly significant difference among the regions. Comparatively similar PC1 were found in fish from Kuakata and Bhola regions but had a significant difference in fish from both Sundarbans and Cox's Bazar regions $(p<0.001)$. The fish from the Sundarbans region had comparatively larger heads, body,

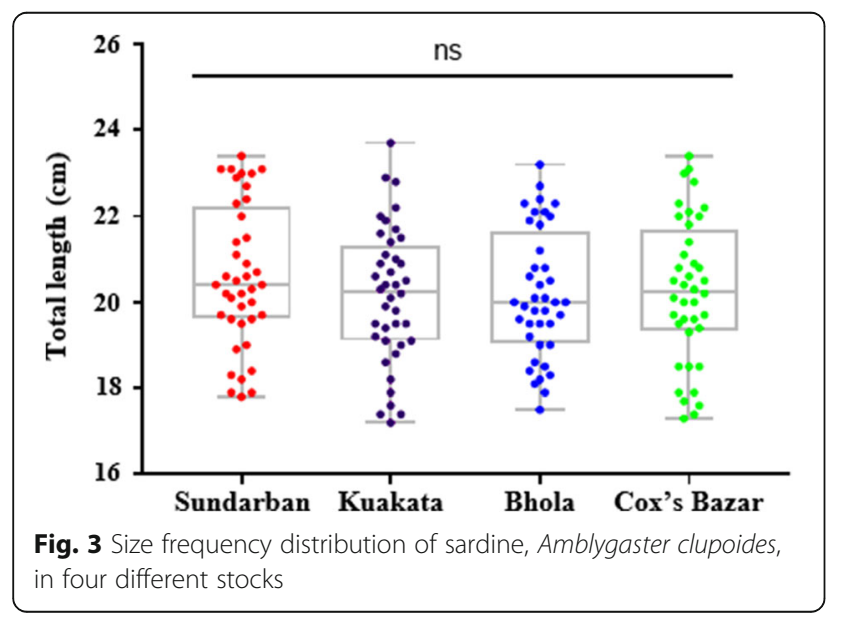

Table 4 ANOVA of morphometric characters for A. clupeoides samples collected from the Bay of Bengal coast, Bangladesh

\begin{tabular}{|c|c|c|c|}
\hline Distance code & Wilks' lambda & $F$ value & $p$ value \\
\hline$\overline{\mathrm{HL} 1}$ & 0.229 & 175.203 & $0.00^{*}$ \\
\hline$M L$ & 0.524 & 47.200 & $0.00^{*}$ \\
\hline BL 1 & 0.728 & 19.400 & $0.00^{*}$ \\
\hline BD 1 & 0.671 & 25.550 & $0.00^{*}$ \\
\hline $\mathrm{HH} 1$ & 0.552 & 42.279 & $0.00^{*}$ \\
\hline HD 1 & 0.602 & 34.354 & $0.00^{*}$ \\
\hline HD 2 & 0.692 & 23.191 & $0.00^{*}$ \\
\hline DFL & 0.627 & 30.952 & $0.00^{*}$ \\
\hline BD 2 & 0.743 & 17.973 & $0.00^{*}$ \\
\hline $\mathrm{BH} 1$ & 0.739 & 18.412 & $0.00^{*}$ \\
\hline BD 3 & 0.695 & 22.771 & $0.00^{*}$ \\
\hline BL 2 & 0.577 & 38.145 & $0.00^{*}$ \\
\hline BD 4 & 0.605 & 33.943 & $0.00^{*}$ \\
\hline BD 5 & 0.626 & 31.093 & $0.00^{*}$ \\
\hline BD 6 & 0.654 & 27.554 & $0.00^{*}$ \\
\hline BD 7 & 0.504 & 51.238 & $0.00^{*}$ \\
\hline$C L 1$ & 0.568 & 39.514 & $0.00^{*}$ \\
\hline $\mathrm{BH} 2$ & 0.555 & 41.631 & $0.00^{*}$ \\
\hline CLD & 0.867 & 7.957 & $0.00^{*}$ \\
\hline BD 8 & 0.700 & 22.298 & $0.00^{*}$ \\
\hline $\mathrm{CL} 2$ & 0.945 & 3.018 & 0.03 \\
\hline$B L 3$ & 0.935 & 3.618 & 0.02 \\
\hline AFL & 0.854 & 8.924 & $0.00^{*}$ \\
\hline BL 4 & 0.850 & 9.158 & $0.00^{*}$ \\
\hline BL 5 & 0.676 & 24.876 & $0.00^{*}$ \\
\hline BD 9 & 0.755 & 16.829 & $0.00^{*}$ \\
\hline $\mathrm{HL} 2$ & 0.678 & 24.666 & $0.00^{*}$ \\
\hline HD 3 & 0.728 & 19.475 & $0.00^{*}$ \\
\hline
\end{tabular}

All abbreviations as in Table 2

*Significance level $p<0.001$

and tail. Significantly different PC1 was also found among Cox's Bazar, Kuakata, and Bhola regions $(p<$ 0.001). Fish samples from Kuakata and Bhola regions had a comparatively larger body form than the samples collected from Cox's Bazar.

PC2 described mainly body form morphology with a single part of the head (HL1), body height (BH1), body diagonal (BD5 and BD6), and anal fin length (AFL) (Fig. 5). PC1 score means $(p<0.001)$ indicated a significant difference among the regions. Fish from the Cox's Bazar region had a comparatively compressed body form compared to the other regions, while fishes from Sundarbans region possessed a longer and stiffen body form. PC2 scores differed significantly from the Kuakata and Bhola as in these two regions more or less similar body 
Table 5 Eigenvalues, percentage of variance, and percentage of cumulative variance for the five factors of A. clupeoides for truss morphometric measurements

\begin{tabular}{llll}
\hline Factors & Eigenvalues & $\begin{array}{l}\text { Percentage } \\
\text { of variance }\end{array}$ & $\begin{array}{l}\text { Percentage of } \\
\text { cumulative variance }\end{array}$ \\
\hline PC1 & 16.92 & 60.42 & 60.42 \\
PC2 & 2.71 & 9.69 & 70.11 \\
PC3 & 1.57 & 5.61 & 75.72 \\
PC4 & 1.40 & 5.01 & 80.73 \\
PC5 & 1.13 & 4.02 & 84.75 \\
\hline
\end{tabular}

Table 6 Results of factors extraction in PC analysis after varimax normalized rotation in A. clupeoides from the Bay of Bengal coast, Bangladesh

\begin{tabular}{|c|c|c|c|c|c|}
\hline Landmark distance code & PC1 & PC2 & PC3 & PC4 & PC5 \\
\hline$\overline{\mathrm{HL}} 1$ & 0.571 & -0.659 & & & \\
\hline$M L$ & -0.724 & & & & \\
\hline BL 1 & 0.639 & & & 0.448 & -0.478 \\
\hline BD 1 & -0.868 & & & & \\
\hline $\mathrm{HH} 1$ & -0.810 & & & & \\
\hline HD 1 & 0.511 & & & 0.673 & \\
\hline HD 2 & 0.655 & & & 0.573 & \\
\hline DFL & -0.589 & & & & 0.789 \\
\hline $\mathrm{BD} 2$ & 0.447 & & 0.897 & & \\
\hline $\mathrm{BH} 1$ & 0.547 & -0.672 & & & \\
\hline $\mathrm{BD} 3$ & -0.934 & & & & \\
\hline BL 2 & -0.942 & & & & \\
\hline $\mathrm{BD} 4$ & 0.876 & & & & \\
\hline $\mathrm{BD} 5$ & 0.508 & 0.617 & & & \\
\hline BD 6 & 0.584 & 0.647 & & & \\
\hline $\mathrm{BD} 7$ & -0.749 & & -0.403 & & \\
\hline $\mathrm{CL} 1$ & 0.625 & & & 0.444 & \\
\hline $\mathrm{BH} 2$ & 0.517 & & & & 0.817 \\
\hline CLD & 0.454 & & 0.627 & & \\
\hline $\mathrm{BD} 8$ & 0.855 & & & & \\
\hline $\mathrm{CL} 2$ & 0.594 & & 0.401 & -0.496 & \\
\hline$B L 3$ & & & & & 0.431 \\
\hline AFL & 0.509 & 0.724 & & & \\
\hline BL 4 & 0.490 & & & 0.690 & \\
\hline BL 5 & 0.839 & & & & \\
\hline $\mathrm{BD} 9$ & 0.616 & & 0.406 & & \\
\hline HL 2 & -0.535 & & & -0.835 & \\
\hline HD 3 & 0.852 & & & & \\
\hline
\end{tabular}

Significant loadings $>0.60$ shape were observed than two other regions, Sundarbans and Cox's Bazar $(p<0.001)$.

The discriminant function (DF) analysis shows three morphological indices defining 93.9\% (DF1), 5.8\% (DF2), and $0.3 \%$ (DF3) of the morphological difference (Table 7) . The truss distances with important loading on DF1 were shown in Table 7 with total variance of $93.9 \%$. All of these distances were described as morphometric measurements cover the whole body of the fish. The DF2 elucidated $5.8 \%$ of the total variation, and four measurements in the tail region showed important loading. The DF3 elucidated $0.3 \%$ of the total variance, and four measurements in the body and head region loaded heavily. The DF1 and DF2 plot elucidated $99.7 \%$ of the total difference among the measurements and presented assortment among the stocks of $A$. clupeoides (Fig. 6).

Wilk's lambda $(\lambda)$ test of discriminant function (DF) analysis showed significant variation among morphometric traits of all stocks except the third function because the $p$ value $(p>0.001)$ of the third function is not significant (Table 8).

Discriminant function analysis presented $68.39 \%$ correctly classified individuals into their original populations. The percentage of correctly classified group results were analogous with the result of cross-validation test. The highest proportion of reclassification rate was registered for the Cox's Bazar (85.0\%), followed by the Sundarbans, Kuakata, and Bhola in reducing order $(80 \%$, $77.5 \%$, and $70 \%$ ). Almost similar proportionate were found in the cross validation test, where Cox's Bazar contributed maximum amount $(75.0 \%)$ following Sundarban (72.5\%), Kuakata (52.5\%) and Bhola (52.5\%). The maximum intermingling was detected among sampling sites, viz. Kuakata and Bhola, Sundarbans and Kuakata, Sundarbans, Kuakata and Bhola, and Cox's Bazar and Bhola (Table 9).The unweighted pair group method with arithmetic mean (UPGMA) analysis resulted in two main clades: the first one includes Bhola, Kuakata, and Sundarbans populations and the second clade consists of Cox's Bazar population (Fig. 7). Similar to the DF analysis results, dendrogram indicated a clear of isolation of Cox's Bazar populations, while high degree of overlapping was found between Kuakata and Bhola, suggesting that the variables were adequate to clearly differentiate Cox's Bazar.

\section{Discussion}

Morphological variation is common within and between populations due to the segregation of a population within the surroundings of native territory. The present study assessed the morphometric variability of $\mathrm{A}$. Clupeoides, and at least three morphologically distinguishable stocks were identified in the coast of the Bay of Bengal, Bangladesh. Phenotypic plasticity could be due 

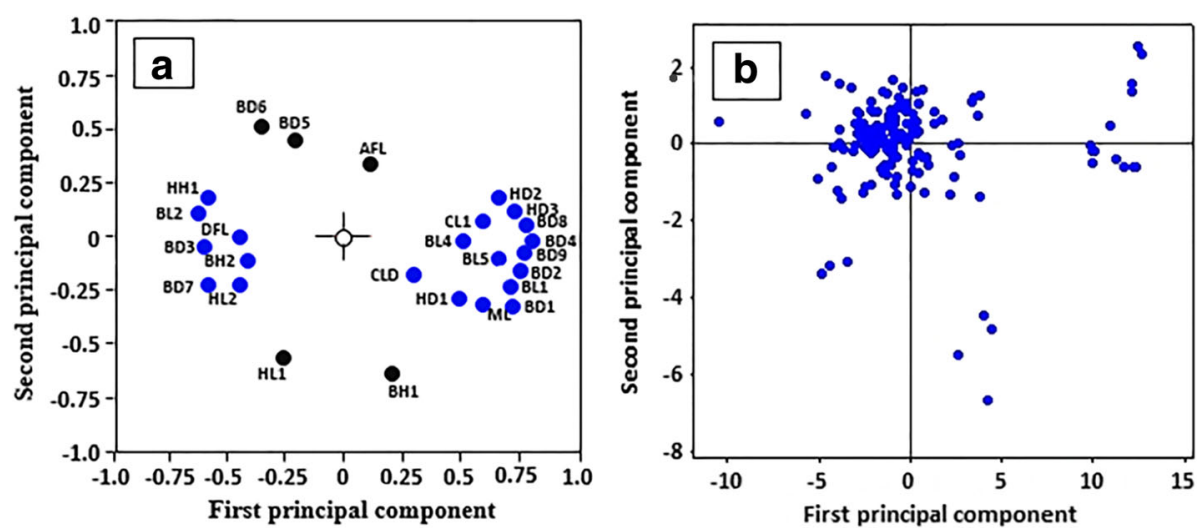

Fig. 4 The principal components analysis on size-corrected truss variables. a The loading plots (PC1, blue dots; PC2, black dots). b The score plots of all individuals

to genetic variations among the stocks (Robinson \& Wilson, 1996), which would be associated with unusual aquatic circumstances, i.e., temperatures, salinity, turbidity, current pattern, and alkalinity (Hanif et al., 2019; Mir et al., 2012). However, similarities between stocks may be the consequence of homogenous environmental factors and habitat characteristics.

The results of DFA analysis demonstrated that except for Bhola and Kuakata specimens, the morphometric variability was relatively higher between different populations. PC analysis demonstrated that the difference in morphometric traits was apparent in the head, body, and caudal region among the populations of A. clupeoides. Sundarbans and Cox's Bazar populations were well separated which may be ascribed to the geographic distances between the rivers and limited migration in these waters. The strong phenotypic discreteness of the Sundarbans and Cox's Bazar samples may also indicate resident populations or subspecies of $A$. Clupeoides in these rivers.
The intermingling relationship was highest in Kuakata and Bhola regions which may be attributed to the similar geographical positions and climatic conditions of the two rivers and probable unintended sampling of migratory A. Clupeoides from the Kuakata to the Bhola region; it may also indicate some temporal and spatial residence of individuals from the Kuakata population in the Bhola river. Multivariate analysis (DF and PC) was applied by Hossain (2010) to three populations of $L$. calbasu from two Bangladeshi rivers (Jamuna and Halda) and a hatchery to describe the morphological variation between them. In their study, the possible causes of the variations were local fish migration and environmental factors.

In the present study, in line with the DFA plot, UPGMA cluster also differs the Sundarbans region and Cox's Bazar region from Kuakata and Bhola regions which may be related to geographic distance because it is well known that geographical isolation produces morphological changes (Yamamoto et al., 2006). The

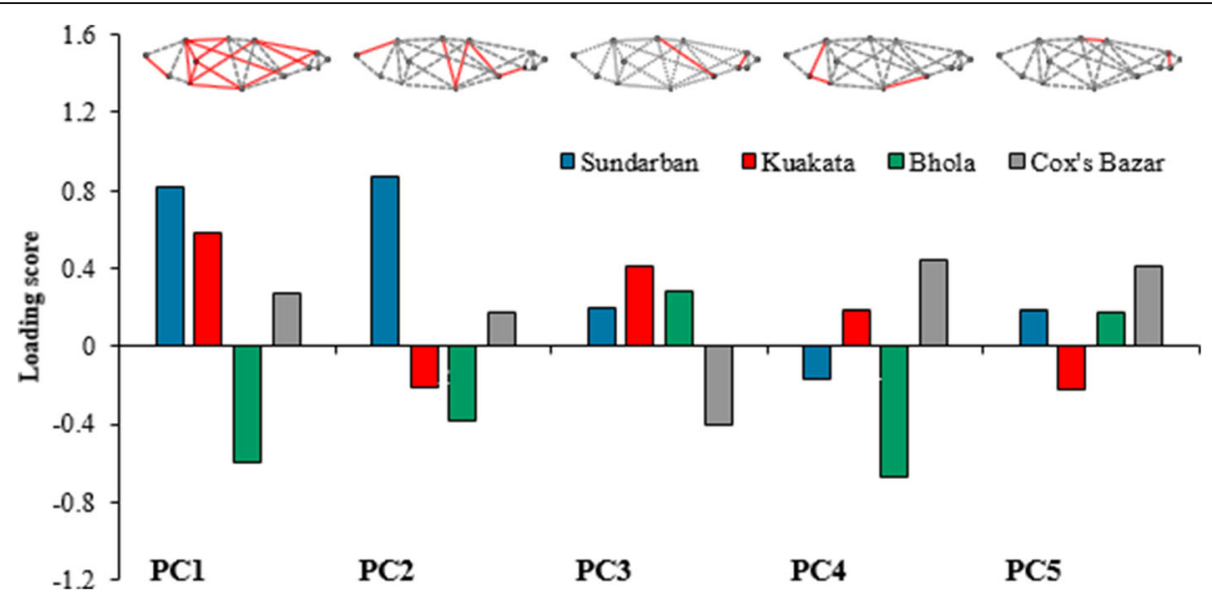

Fig. 5 Variation for the five components in the principle component analysis (PCA) of A. clupeoides collected from the four sampling points along the Bay of Bengal coast, Bangladesh 
Table 7 Contribution of morphometric measurements to discriminant functions (DF) of A. clupeoides collected from the four sampling sites along the Bay of Bengal coast, Bangladesh

\begin{tabular}{|c|c|c|c|}
\hline Landmark distance code & DF1 (93.9\%) & DF2 (5.8\%) & DF3 (0.3\%) \\
\hline $\mathrm{HL} 1$ & $0.940^{*}$ & -0.010 & 0.018 \\
\hline$M L$ & $0.482^{*}$ & 0.294 & 0.290 \\
\hline BL 1 & $0.465^{*}$ & 0.304 & 0.257 \\
\hline BD 1 & $0.449^{*}$ & 0.249 & 0.183 \\
\hline $\mathrm{HH} 1$ & $0.417^{*}$ & 0.194 & 0.317 \\
\hline HD 1 & $0.379^{*}$ & 0.308 & 0.262 \\
\hline HD 2 & $0.371^{*}$ & 0.347 & 0.199 \\
\hline DFL & $0.364^{*}$ & 0.281 & 0.270 \\
\hline BD 2 & $0.354^{*}$ & 0.079 & 0.251 \\
\hline BH 1 & $0.349^{*}$ & 0.142 & 0.193 \\
\hline BD 3 & $0.343^{*}$ & 0.062 & 0.311 \\
\hline BL 2 & $0.326^{*}$ & 0.250 & 0.154 \\
\hline BD 4 & $0.325^{*}$ & 0.300 & 0.240 \\
\hline BD 5 & $0.315^{*}$ & 0.000 & 0.127 \\
\hline BD 6 & $0.308^{*}$ & 0.213 & 0.263 \\
\hline BD 7 & $0.305^{*}$ & 0.279 & 0.205 \\
\hline CL 1 & $0.277^{*}$ & 0.109 & 0.271 \\
\hline $\mathrm{BH} 2$ & $0.235^{*}$ & 0.103 & 0.223 \\
\hline CLD & $0.156^{*}$ & -0.041 & 0.114 \\
\hline BD 8 & $0.126^{*}$ & -0.007 & 0.072 \\
\hline CL 2 & 0.378 & $0.467^{*}$ & 0.361 \\
\hline BL 3 & 0.275 & $0.415^{*}$ & 0.163 \\
\hline AFL & 0.242 & $0.304^{*}$ & 0.259 \\
\hline BL 4 & -0.091 & $0.170^{*}$ & 0.003 \\
\hline BL 5 & 0.278 & -0.555 & $0.703^{*}$ \\
\hline BD 9 & 0.429 & 0.472 & $0.657^{*}$ \\
\hline HL 2 & 0.362 & 0.089 & $0.377^{*}$ \\
\hline HD 3 & 0.183 & 0.100 & $0.269^{*}$ \\
\hline
\end{tabular}

All abbreviations as in Table 2

*Largest correlation between each variable and DF

Sundarbans region is situated in the southwestern coast of Bangladesh, while the Kuakata and Bhola regions are in the middle coast and the Cox's Bazar region is situated in the southeastern coast of the country. The distance between Sundarbans to Kuakata is about $81.17 \mathrm{~km}$, Kuakata to Bhola $52.22 \mathrm{~km}$, and Bhola to Cox's Bazar $141.73 \mathrm{~km}$.

Morphological differences in factor 1 of A. Clupeoides could be due to its feeding behavior as for predator evasiveness and foraging adeptness, high locomotory performance is crucial (Chipps, Dunbar, \& Wahl, 2004; Swain, Hutchings, Foote, Cadrin, \& Friedland, 2005). For taking the optimum amount of food, body depth adaptations are essential for transient and topical swimmers (Pazhayamadom et al., 2014). It is reported that the deep

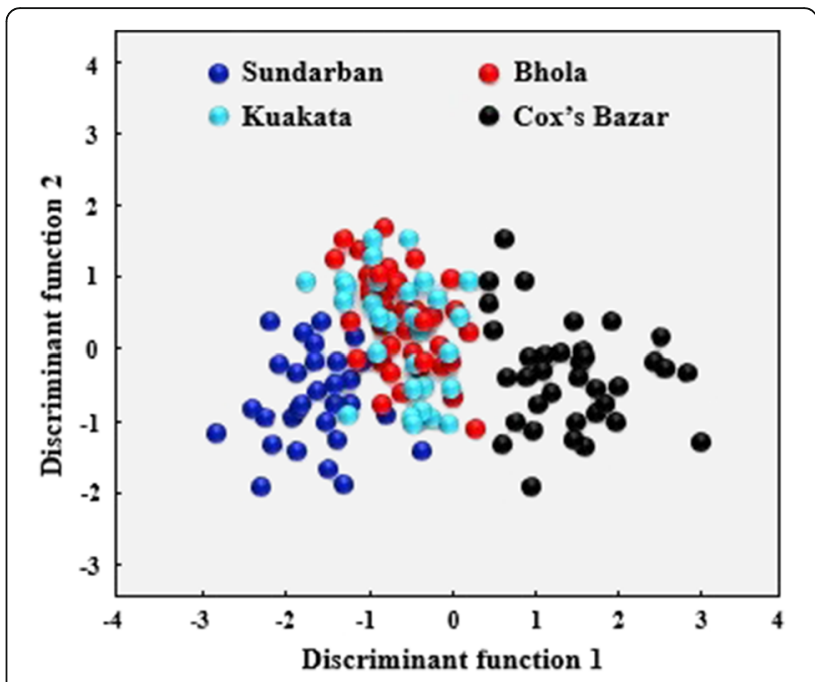

Fig. 6 Discriminant function (DF) analysis plot with 28 morphometric variables for $A$. clupeoides collected from the four sampling points along the Bay of Bengal coast, Bangladesh

healthy fish stocks from less turbulent waters perform faster speed with brief propulsion (Blake, 2004; Webb, 1984). The eastern coast of the Bay of Bengal is more turbid than the western coast (Chamarthi, Ram, \& Josyula, 2008). Thus, the Sundarbans region is less turbulent in comparison to the Cox's Bazar region. The population of Cox's Bazar had comparatively more streamlined body which may be an adjustment toward food searching in the turbulent waters. The second factor component was loaded heavily with truss distances representing the region across the head length, body height, body diagonal, and anal fin length. The variables with high loadings (BH 1 BD 5 and BD 6) in factor 2 may not be due to shape variations that represented the distinctness of stock, but most probably linked with the feeding biology of $A$. clupeoides. The most preferred food species of $A$. clupeoides is zooplankton, predominantly copepods, which are highly abundant in the Sundarbans region (west coast). Most fish samples collected from the Sundarbans region were observed with a swollen belly that was significantly different from other sampling sites.

The morphological divergence is exclusively associated to body shape but not to size. Traits related to

Table 8 Results of Wilks' lambda test for verifying differences among populations of $A$. clupeoides collected from the four sampling sites along the Bay of Bengal coast, Bangladesh

\begin{tabular}{lllll}
\hline Test of functions & Wilks' lambda & Chi-square & df & Sig. \\
\hline 1 through 3 & 0.166 & 278.057 & 12 & 0.000 \\
2 through 3 & 0.801 & 34.391 & 6 & 0.000 \\
3 & 0.989 & 1.684 & 2 & 0.431 \\
\hline
\end{tabular}


Table 9 Percentage of specimens classified into each group and after cross-validation for morphometric data

\begin{tabular}{|c|c|c|c|c|c|c|c|c|c|c|}
\hline & \multicolumn{4}{|c|}{ Original group } & \multirow[t]{2}{*}{ Total } & \multicolumn{4}{|c|}{ Cross-validated group } & \multirow[t]{2}{*}{ Total } \\
\hline & Sundarbans & Kuakata & Bhola & Cox's Bazar & & Sundarbans & Kuakata & Bhola & Cox's Bazar & \\
\hline Sundarbans & 80.0 & 12.5 & 7.5 & 0.0 & 100.0 & 72.5 & 20.0 & 7.5 & 0.0 & 100.0 \\
\hline Kuakata & 5.0 & 77.5 & 17.5 & 0.0 & 100.0 & 10.0 & 52.5 & 37.5 & 0.0 & 100.0 \\
\hline Bhola & 0.0 & 30.0 & 70.0 & 0.0 & 100.0 & 7.5 & 40.0 & 52.5 & 0.0 & 100.0 \\
\hline Cox's Bazar & 0.0 & 5.0 & 10.0 & 85.0 & 100.0 & 0.0 & 15.0 & 10.0 & 75.0 & 100.0 \\
\hline
\end{tabular}

size can make the result error if not removed from the data during morphometric analysis (Yakubu \& Okunsebor, 2011). In the present study, morphological variation within the coast of the Bay of Bengal may be linked with head and body shape differences; as by using allometric transformation, the size effect for morphometric data was successfully removed. However, further studies need to be done through molecular genetic studies to verify the present results.

\section{Conclusion}

The truss-based technique can be effectively applied to examine the variation of stocks within a species, which has been previously described for many species in both marine and freshwater habitats. The present study based on truss morphometric technique exposed a clear variation in the wild stocks of $A$. clupeoides at the four sampling regions of the Bay of Bengal coast, Bangladesh, recommending a need for distinct management approaches to protect the stocks of A. clupeoides and ensure its sustainability. However, molecular distinction along with morphological attributes provides important information about a species to formulate scientifically

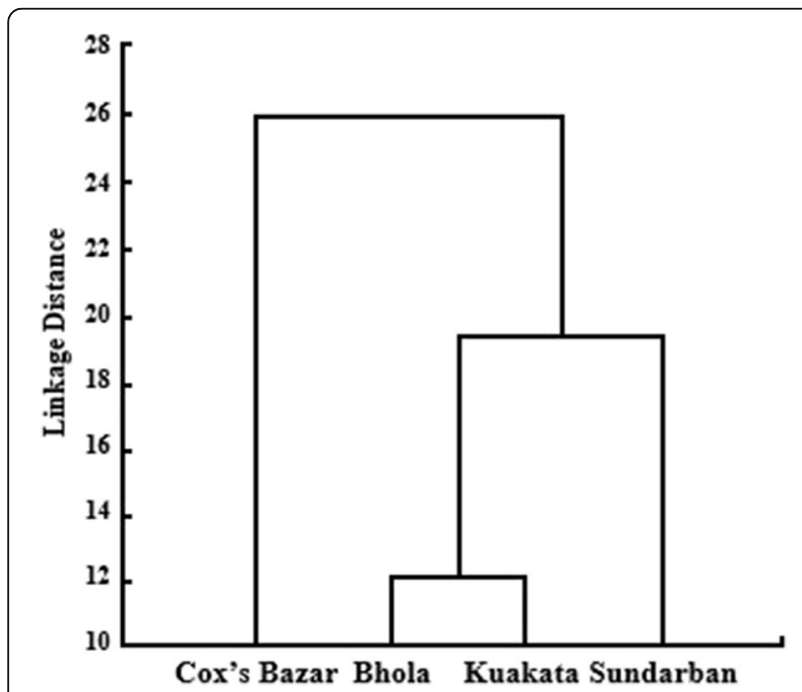

Fig. 7 Dendrogram resulting from the cluster analysis of Euclidean distances among A. clupeoides collected from the four sampling points along the Bay of Bengal coast, Bangladesh robust fisheries management strategies of particular species in distinct habitats (Dowling, Anderson, Marsh, \& Rosenberg, 2015).

\section{Abbreviations}

ANOVA: Analysis of variance; CA: Cluster analysis; CSBN: Coastal set bag net; DFA: Discriminant function analysis; PCA: Principal component analysis; UPGMA: Unweighted pair group method with arithmetic mean

\section{Acknowledgements}

The authors are thankful to those fishermen who help to catch the specimens of selected fish. The authors are also very grateful to the editor and reviewers for their valuable feedback and recommendations.

\section{Authors' contributions}

MAH designed the study, selected the species, collected the samples and data, analyzed the data, and prepared the first draft of the manuscript. MABS and AN proposed and coordinated the study and prepared the final manuscript. MAI collected the data and revised the draft manuscript. MRC carried out the partial statistical analysis. All authors read and approved the final manuscript.

\section{Funding}

The authors did not receive any fund from any funding organization, institution, or agency.

\section{Availability of data and materials}

The datasets generated and analyzed during the current study are available from the corresponding author on reasonable request.

\section{Ethics approval and consent to participate}

Ethical approval was not a prerequisite in the present study as the mentioned study areas are not privately owned or protected areas, as well as did not involve endangered or protected species. However, samples were transported to the laboratory very carefully to avoid transport-related damage.

\section{Consent for publication}

Not applicable

\section{Competing interests}

The authors declare that they have no competing interests.

\section{Author details}

'Department of Fisheries Biology and Genetics, Patuakhali Science and Technology University, Patuakhali 8602, Bangladesh. ${ }^{2}$ WorldFish, Bangladesh and South Asia Office, Dhaka, Bangladesh. ${ }^{3}$ School of Molecular and Life Sciences, Curtin University, Bentley 6102, WA, Australia. ${ }^{4}$ Department of Marine Fisheries and Oceanography, Patuakhali Science and Technology University, Patuakhali 8602, Bangladesh.

Received: 23 November 2018 Accepted: 27 May 2019

Published online: 17 July 2019

\section{References}

Blake, R. W. (2004). Fish functional design and swimming performance. Journal of Fish Biology, 65, 1193-1222. https://doi.org/10.1111/j.0022-1112.2004.00568.x

Chaklader, M. R., Siddik, M. A. B., Hanif, M. A., Nahar, A., Sultan, M., \& Piria, M. (2016). Morphometric and meristic variation of endangered Pabda catfish, Ompok pabda (Hamilton-Buchanan, 1822) from southern coastal 
waters of Bangladesh. Pakistan Journal of Zoology, 48, 681-687 EID: 2-s2. 0-84968725288.

Chamarthi, S., Ram, P. S., \& Josyula, L. (2008). Effect of river discharge on Bay of Bengal circulation. Marine Geodesy, 31, 160-168. https://doi.org/10.1080/ 01490410802265476.

Chipps, S. R., Dunbar, J. A., \& Wahl, D. H. (2004). Phenotypic variation and vulnerability to predation in juvenile bluegill sunfish (Lepomis macrochirus). Oecologia, 138, 32-38. https://doi.org/10.1007/s00442-003-1396-z.

Cronin-Fine, L., Stockwell, J. D., Whitener, Z. T., Labbe, E. M., Willis, T. V., \& Wilson, K. A. (2015). Application of morphometric analysis to identify alewife stock structure in the Gulf of Maine. Marine and Coastal Fisheries, 5, 11-20. https:// doi.org/10.1080/19425120.2012.741558.

Dowling, T. E., Anderson, C. D., Marsh, P. C., \& Rosenberg, M. S. (2015). Population structure in the Roundtail Chub (Gila robusta Complex) of the Gila River Basin as determined by microsatellites: Evolutionary and conservation implications. PLoS One. https://doi.org/10.1371/journal.pone.0139832.

Elliott, N. G., Haskard, K., \& Koslow, J. A. (1995). Morphometric analysis of orange roughly (Hoplostethus atianticus) off the continental slope of Southern Australia. Journal of Fish Biology, 46, 202-220. https://doi.org/10.1111/j.10958649.1995.tb05962.x.

Francoy, T. M., Franco, F. F., \& Roubik, D. W. (2012). Integrated landmark and outline-based morphometric methods efficiently distinguish species of Euglossa (Hymenoptera, Apidae, Euglossini). Apidologie (Celle), 43, 609-617. https://doi.org/10.1007/s13592-012-0132-2.

Galeotti, D. M., Castalanelli, M. A., Groth, D. M., McCullough, C., \& Lund, M. (2015). Genotypic and morphological variation between Galaxiella nigrostriata (Galaxiidae) populations: Implications for conservation. Marine and Freshwater Research, 66, 187-194. https://doi.org/10.1071/MF13289.

Hanif, M. A., Chaklader, M. R., Siddik, M. A. B., Nahar, A., Foysal, M. J., \& Kleindienst, R. (2019). Phenotypic variation of gizzard shad, Anodontostoma chacunda (Hamilton, 1822) based on truss network model. Regional Studies in Marine Science, 25, 100442. https://doi.org/ 10.1016/j.rsma.2018.100442.

Hanif, M. A.s Siddik, M. A. B., Chaklader, M. R., Nahar, A., \& Mahmud, S. (2015). Fish diversity in the southern coastal waters of Bangladesh: Present status, threats and conservation perspectives. Croatian Journal of Fisheries, 73, 148-161. https://doi.org/10.14798/73.4.848.

Hanif, M. A., Siddik, M. A. B., Chaklader, M. R., Pham, H. D., \& Kleindienst, R. (2017). Length-weight relationships of three catfish species from a tributary of the Dhaleshwari River, Bangladesh. Journal of Applied Ichthyology, 33(6), 12611262. https://doi.org/10.1111/jai.13448.

Hanif, M. A., Siddik, M. A. B., Nahar, A., Chaklader, M. R., \& Fotedar, R. (2017). A new distribution of the buffon's river garfish, Zenarchopterus buffonis (Valenciennes, 1847) in the southern coastal rivers of Bangladesh. Journal of Applied Ichthyology, 33(6), 1211-1214. https://doi.org/10.1111/jai.13462.

Hossain, M. A. R., Nahiduzzaman, M., Saha, D., Khanam, M. U. H., \& Alam, M. S. (2010). Landmark-Based Morphometric and Meristic Variations of the Endangered Carp, Kalibaus Labeo calbasu, from Stocks of Two Isolated Rivers, the Jamuna and Halda, and a Hatchery. Zoological Studies, 49, 556-563.

Hussain, M. G., \& Hoq, M. E. (2010). Sustainable management of fisheries resources of the Bay of Bengal. Support to sustainable management of the BOBLME project, Bangladesh Fisheries Research Institute SBOBLMEP Pub./Rep. 2, 122 p. ISBN: 978-984-33-1680-6.

Islam, M. A., Siddik, M. A. B., Hanif, M. A., Chaklader, M. R., Nahar, A., \& Ilham, I. (2017). Length-weight relationships of four small indigenous fish species from an inland artisanal fishery, Bangladesh. Journal of Applied Ichthyology, 33(4), 851-852. https://doi.org/10.1111/jai.13374.

Mir, J. I., Sarkar, U. K., Dwivedi, A. K., Gusain, O. P., \& Jena, J. K. (2012). Stock structure analysis of Labeo rohita (Hamilton, 1822) across the Ganga basin (India) using a truss network system. Journal of Applied Ichthyology, 29, 10971103. https://doi.org/10.1111/jai.12141.

Pazhayamadom, D. G., Chakraborty, S. K., Jaiswar, A. K., Sudheesan, D., Sajina, A. M., \& Jahageerdar, S. (2014). Stock structure analysis of 'Bombay duck' (Harpadon nehereus Hamilton, 1822) along the Indian coast using truss network morphometrics. Journal of Applied Ichthyology, 31(1), 37-44. https://doi.org/10.1111/jai.12629.

Randall, J. E., Williams, J. T., Smith, D. G., Kulbicki, M., Tham, G. M., Labrosse, P., .. Mann, B. S. (2004). Checklist of the shore and epipelagic fishes of Tonga. Atoll Research Bulletin, 1-35. https://doi.org/10.5479/si.00775630.502.1.

Robinson, B. W., \& Wilson, D. S. (1996). Genetic variation and phenotypic plasticity in a trophically polymorphic population of pumpkinseed sunfish (Lepomis gibbosus). Evolutionary Ecology, 10, 631-652. https://doi.org/10.1007/BF01237711.

Samaee, S. M., Patzner, R. A., \& Mansour, N. (2009). Morphological differentiation within the population of Siah mahi, Capoeta Capoeta gracilis, (Cyprinidae, Teleostei) in a river of the south Caspian Sea basin: A pilot study. Journal of Applied Ichthyology, 25, 583-590. https:/doi.org/10.1111/.1.1439-0426.2009.01256.x.

Sen, S., Jahageerdar, S., Jaiswar, A. K., Chakraborty, S. K., Sajina, A. M., \& Dash, G. R. (2011). Stock structure analysis of Decapterus russelli (Ruppell, 1830) from east and west coast of India using truss network analysis. Fisheries Research, 112, 38-43. https://doi.org/10.1016/j.fishres.2011.08.008.

Siddik, M. A. B., Chaklader, M. R., Hanif, M. A., Islam, M. A., \& Fotedar, R. (2016). Length-weight relationships of four fish species from a coastal artisanal fishery, southern Bangladesh. Journal of Applied Ichthyology, 32, 1300-1302. https://doi.org/10.1111/jai.13181.

Siddik, M. A. B., Chaklader, M. R., Hanif, M. A., Nahar, A., Ilham, I., Cole, A., \& Fotedar, R. (2016). Variation in the life-history traits of a Schilbid catfish, Clupisoma garua (Hamilton, 1822) in the waters of southern Bangladesh. Chinese Journal of Oceanology and Limnology, 35(5), 11891196. https://doi.org/10.1007/s00343-017-6008-6.

Siddik, M. A. B., Hanif, M. A., Chaklader, M. R., Nahar, A., \& Fotedar, R. (2016). A multivariate morphometric investigation to delineate stock structure of gangetic whiting, Sillaginopsis panijus (Teleostei: Sillaginidae). SpringerPlus, 5, 520. https://doi.org/10.1186/s40064-016-2143-3.

Siddik, M. A. B., Hanif, M. A., Chaklader, M. R., Nahar, A., \& Mahmud, S. (2015). Fishery biology of gangetic whiting Sillaginopsis panijus (Hamilton, 1822) endemic to Ganges delta, Bangladesh. Egyptian Journal of Aquatic Research, 41, 307-313. https://doi.org/10.1016/j.ejar.2015.11.001.

Silva, A. (2003). Morphometric variation among sardine (Sardina pilchardus) populations from the northeastern Atlantic and the western Mediterranean. ICES Journal of Marine Science, 60, 1352-1360. https://doi.org/10.1016/S1054-3139(03)00141-3.

Solomon, S. G., Okomoda, V. T., \& Ogbenyikwu, A. I. (2015). Intraspecific morphological variation between cultured and wild Clarias gariepinus (Burchell) (Clariidae, Siluriformes). Archives of Polish Fisheries, 23, 53-61. https://doi.org/10.1515/aopf-2015-0006.

Strauss, R. E., \& Bookstein, F. L. (1982). The truss: body form reconstruction in morphometrics.Systematic Zoology, 31, 113-135.

Swain, D. P., Hutchings, J. A., Foote, C. J., Cadrin, S., \& Friedland, K. (2005). Environmental and genetic influences on stock identification characters. In $\mathrm{S}$. X. Cadrin, K. D. Friedland, \& J. R. Waldman (Eds.), Stock identification methods: applications in fishery science. London: Elsevier Academic Press.

Torres, R. G. A., Gonzalez, P. S., \& Pena, S. E. (2010). Anatomical, histological and ultraestructural description of the gills and liver of the tilapia (Oreochromis niloticus). International Journal of Morphology, 28, 703-712.

Turan, C. (2004). Stock identification of Mediterranean horse mackerel (Trachurus mediterraneus) using morphometric and meristic characters. ICES Journal of Marine Science, 61, 774-781. https://doi.org/10.1016/j.icesjms.2004.05.001.

Vatandoust, S., Mousavi-Sabet, H., Razeghi-Mansour, M., AnvariFar, H., \& Heidari, A. (2015). Morphometric variation of the endangered Caspian lamprey, Caspiomyzon wagneri (Pisces: Petromyzontidae), from migrating stocks of two rivers along the southern Caspian Sea. Zoological Studies, 54, 56. https://doi.org/10.1186/s40555-015-0133-8.

Veasey, E. A., Schammass, E. A., Vencovsky, R., Martins, P. S., \& Bandel, G. (2001). Germplasm characterization of Sesbania accessions based on multivariate analyses. Genetic Resources and Crop Evolution, 48, 79-90. https://doi.org/10.1023/A:1011238320630.

Wantiez, L. (1993). Les poissons des fonds meubles du lagon Nord et de la Baie de SaintVincent de Nouvelle-Calédonie: Description des peuplements, structure et fonctionnement des communautés. France: Ph.D. Thesis, Université d' Aix-Marseille II.

Webb, P. W. (1984). Body Form, Locomotion and Foraging in Aquatic Vertebrates. American Zoologist, 24, 107-120.

Yakubu, A. \& Okunsebor, S. A. (2011). Morphometric differentiation of two Nigerian fish species (Oreochromis niloticus and Lates niloticus) using principal components and discriminant analysis. International Journal of Morphology, 29, 1429-1434.

Yamamoto, S., Maekawa, K., Tamate, T., Koizumi, I., Hasegawa, K., \& Kubota, H. (2006). Genetic evaluation of translocation in artificially isolated populations of white-spotted Charr (Salvelinus leucomaenis). Fisheries Research, 78, 352358. https://doi.org/10.1016/j.fishres.2005.11.011.

\section{Publisher's Note}

Springer Nature remains neutral with regard to jurisdictional claims in published maps and institutional affiliations. 